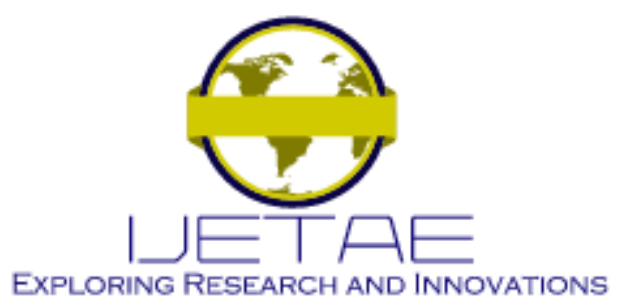

International Journal of Emerging Technology and Advanced Engineering

Website: www.ijetae.com (E-ISSN 2250-2459, Scopus Indexed, ISO 9001:2008 Certified Journal, Volume 11, Issue 11, November 2021)

Manuscript Received: 04 October 2021, Received in Revised form: 07 November 2021, Accepted: 11 November 2021

DOI: 10.46338/ijetae1121_18

\title{
Copyright Regulation of Relations with regard to Software: Current State and Perspectives
}

\author{
Olena Pikhurets ${ }^{1}$, Stepan Lytvyn ${ }^{2}$, Ivan Miroshnykov ${ }^{3}$, Viktoriia Mykolaiets ${ }^{4}$, Oksana Karashchuk $^{5}$ \\ ${ }^{1}$ Kharkiv National University of Internal Affairs, Kharkiv, Ukraine \\ ${ }^{2}$ Uzhhorod National University, Uzhhorod, Ukraine \\ ${ }^{3}$ Yaroslav Mudryi National Law University, Ukraine \\ ${ }^{4}$ University of the State Fiscal Service of Ukraine, Ukraine \\ ${ }^{5}$ Taras Shevchenko National University of Kyiv, Kyiv, Ukraine
}

\begin{abstract}
The legal regulation of relations about software (computer programs) is conducted mainly in two directions: copyright and patent law. But despite lengthy discussions in scientific circles in almost all countries, there is no final and single solution to this issue. Historically, the model of copyright protection of the object under study offers a cheaper and faster procedure than the model of protection of software by patent law. Patent protection requires a rather expensive and lengthy examination of software for world (absolute) novelty, during which the object itself may become obsolete and become unpopular with potential users. Therefore, the copyright regime for the protection of software has received preferential recognition.

Accordingly, the article attempts to investigate the problems of the existing in the world copyright model of software protection and the possibility of patenting them.
\end{abstract}

Keywords - software, copyright, patent law, object of protection.

\section{INTRODUCTION}

In the conditions of development of innovative society on the basis of information technologies and communications, strengthening of competition of the parties in urgency and significance of the intellectual resources realized through information systems and networks, the software has an important role and value.

Around the middle of the XX century and until now, the study of software relations has been of interest to a large number of scholars in various fields of knowledge and practice, and, accordingly, has occupied a niche in the legislation of most countries. Thus, at the legislative level, the connection between software and the results of intellectual and creative activity is established, and the possibility of legal protection by copyright is established for it.
Undoubtedly, software occupies a special place among the objects of intellectual property rights, and consists of a set of computer programs (software component of the information system), which provide the implementation of information processes by information system devices (hardware component of the information system).

The state has repeatedly emphasized the creation of favourable conditions for the development of the software industry, as having a decisive influence on the innovation regime of the economy. In fact, the software industry is the most high-tech and highly profitable sector of Ukraine's economy. Its feature and difference from other areas of technology is that it does not require significant investment from the state, does not require large natural resources, is environmentally friendly and contributes to the high scientific, intellectual and technological potential of the country.

The pace and scope of involvement of information technology in society, large-scale development of programs and software and their systems raise questions about the development of legislation in this area to ensure the proper exercise of software rights and protect the rights and interests of all stakeholders, involved in this process. This applies primarily to the authors of the software product; its consumers and users, as well as structures responsible for security in the technological support of information processes. Accordingly, in the field of intellectual property law it is necessary to bring a systemic system, especially those that regulate the copyright of computer software developers, their relations with employers, to introduce organizational and legal mechanisms for their use. In this sense, it is necessary to reconsider the established model of copyright in the legal protection of software in order to find ways to ensure proper legal protection of software. 


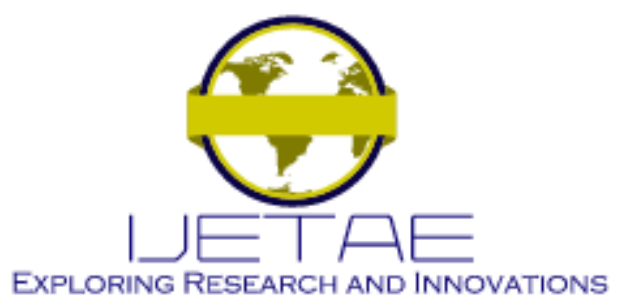

International Journal of Emerging Technology and Advanced Engineering

Website: www.ijetae.com (E-ISSN 2250-2459, Scopus Indexed, ISO 9001:2008 Certified Journal, Volume 11, Issue 11, November 2021)

It is also possible to properly assess non-traditional forms of protection: within the framework of patent law or sui generis.

The problem research status. Important in our study are the works of scholars working in the field of intellectual property law. At the same time, a number of issues concerning the possibility of applying the patent protection model of software remain unresolved.

The aim and objective of the research, there is a study of the problems of the existing in Ukraine copyright model of protection of software and the possibility of their patenting and preparation of recommendations for improving existing legislation and bringing it into line with today's requirements and the needs of software market participants.

The methodological basis of the study are general scientific methods, including the dialectical method and private-scientific methods, including the comparative-legal method, which allowed to study the rules of law governing the relationship to software; empirical method of studying legislation and law enforcement practice, as well as logical and formal-legal methods that allowed to systematize and describe the results of this study for further use.

\section{Materials AND ReSEARCh MethodS}

The legal regulation of relations in relation to software is conducted mainly in two directions: copyright and patent law. But despite lengthy discussions in scientific circles in almost all countries, the final and only solution on this issue is currently lacking. But despite numerous scientific studies, the law of the World Trade Organization (WTO) remains ambiguous on this issue. On the one hand, WTO members must establish protection of software similar to the protection of literary works, and on the other - due to the lack of any prohibition on patenting software in WTO law, it is increasingly used in practice in the USA and EU.

This ambiguity has led to the creation of different legal regimes for software. Thus, the point of view is beginning to stand out that it is expedient to use copyright for program protection, and patent law for algorithms. At the same time, the analysis of legislative acts in the field of intellectual property rights shows that in Ukraine, unlike the EU, basic changes in legislation have not yet taken place. Laws of Ukraine "On Copyright and Related Rights" and "On Protection of Inventions and Utility Models" have recently undergone significant changes, but this is clearly not enough, especially when it comes to such a special object as software.
The law enforcement and legislative practice of most countries of the world has followed the path of protection of software with the application of copyright, which is a direct consequence of generally accepted world practice. This is only because obtaining copyright protection for software is a cheaper and faster procedure than patent protection.

Direct legal regulation in Ukraine of relations related to the legal protection of software is carried out in accordance with the Law of Ukraine "On Copyright and Related Rights" and the Civil Code of Ukraine, which generally meet the requirements of international legal acts. Thus, the Central Committee of Ukraine in 3 item 1 of Art. 420 refer software to the objects of intellectual property rights, Part 2, paragraph 1 of Art. 433 of the Civil Code of Ukraine and Art. 8 of the Law of Ukraine "On Copyright and Related Rights" interpret software as an object of copyright. That is, national law defines software exclusively as objects of copyright. This issue has been similarly resolved in the EU countries. In paragraph 4 of Art. 433 of the Commercial Codex of Ukraine and Art. 18 of the Law of Ukraine "On Copyright and Related Rights" states that software is subject to the regime of a literary work, regardless of the method or form of expression of software.

This use of copyright provides an exclusive opportunity for right holders to control the use and distribution of their software and thus guarantee themselves an appropriate income. This protection is simple, fast, accessible and covers all types of objective forms of software implementation and applies to programs regardless of the medium (paper, hard disk, $\mathrm{CD}$, etc.), method or form of their expression (program that is read only by a computer object code - is protected to the same extent as a program that is read by humans - source (program) code, compared to other possible options. It is not necessary to conduct a long and expensive examination of the software for absolute (global) novelty, during which the software may become obsolete and unclaimed. One of the most important and significant advantages of copyright protection of software is that the rights to works of science, literature, art arise due to the fact of their creation (Articles 433, 437 of the Civil Code of Ukraine); in order to provide protection, it is sufficient that the software is the result of human creative activity and exists in any objective form (Article 435 of the Civil Code of Ukraine). 


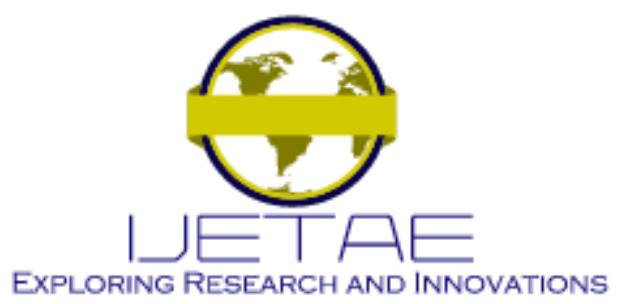

International Journal of Emerging Technology and Advanced Engineering

Website: www.ijetae.com (E-ISSN 2250-2459, Scopus Indexed, ISO 9001:2008 Certified Journal, Volume 11, Issue 11, November 2021)

At EU level, Directive 2009/24 / EU on the legal protection of software of 23.04.2009 and the Agreement on Trade-Related Aspects of Intellectual Property Rights (TRIPS Agreement) 1994 are in force, which also establish copyright legal form of protection for software. According to Art. 10 of the TRIPS Agreement, software, both source and object code, are protected as literary works in accordance with Art. 2 of the Berne Convention (1971). In turn, the WIPO Copyright Treaty of 1996 also refers to a software as an object of copyright, regardless of the manner or form of their expression (Article 4).

However, this approach has provoked discussion in European science [8]. Given that Art. 27 of the TRIPS Agreement states that patents are issued for all inventions, regardless of whether they are "processes» or «products», draws attention to the lack of both in Art. 10, and in Art. 27 of the TRIPS Agreement any mention of the patentability of software. It is probable that the qualification of the legal regime of protection of the «software» as «literary works», specified in Art. 10 of the TRIPS Agreement, was adopted by the countries participating in the trade negotiations in the Uruguay Round. It is possible that the software at that time was perceived as a set of textual and symbolic solutions, and therefore such a sequence can be protected similarly to a literary work. By the nature of the form of display, the lines of a literary work and software have something in common: the lines of a literary work and the lines of software are created by the author with the help of symbols.

Indeed, software are unlike other technologies with a physical nature (electricity or chemistry), given that they do not consist of material substances, but of mathematical components presented in the form of text. Therefore, at first glance, the proximity of programs to technology is deceptive. Moreover, unlike other technical objects, the "created" software can be quickly and easily copied and reproduced to an infinite number of copies. That is why most countries around the world believe that software is closer to literary works and should be protected by copyright law.

Of course, in the case of examination for copyright infringement on literary works or software compare the relevant texts of literary works, and for software - the texts of these programs [2]. Unlike literary works, the text of a software in the form of source or object code has no independent value without the possibility of its application in a computer. The perception of a software, is not directly human, but with the help of a computer [3-5].
Therefore, the conditionality of the affinity of programs with literary works is obvious: the source code written by the programmer has no artistic value.

Today, more and more rights holders and software developers are dissatisfied with the level of protection that their rights to the program receive under copyright, because the main value of software is its functional purpose, the characteristics of which include the algorithm, and the creation of the program language programming is not so important for the user. Much of the creative effort in developing software is focused on design, not code. By protecting the form of software, copyright leaves out its algorithm. That is, the structure, algorithm and ideas underlying the program are not protected and can be freely used by third parties [1-3].

Unlike literary works, the purpose of software is to instruct the computer to achieve a certain result. Without a computer device, such a program has no value. The significance of a software lies not in the source text, but in its work, as a result of which leads to the implementation of a set of commands (instructions) embedded in it. The author (programmer), choosing the form of expression of the source code, is guided not by emotional or aesthetic, but purely practical purpose.

Instead, when choosing a program, the user is guided not by the originality of the software, but by its functional purpose. If the functionality of the program is not useful to the user, he will never buy it.

As a result, copyright protects software from illegal copying and distribution, and independent creation of a program that is similar in functionality to an existing one is not a violation of copyright, even if the author of another program used the principles set forth in the basis of the original program. It is worth noting the following interesting feature: any fragment of any program can be used as a quote in another program. This makes it possible to copy other people's ideas for free and with impunity and make a profit [6-9]. It is known that programs are not created "from scratch", but are developed by the authors using a certain and well-known programming language. The authors, as a rule, use ready-made standard designs. With copyright protection, each newly created program consists of more than half of the existing software. The current copyright system lacks control over the novelty and level of software and algorithms, which contributes to the oversaturation of the market with similar programs and plagiarism of ideas. 


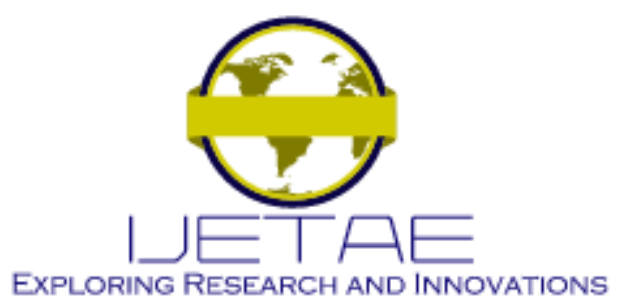

International Journal of Emerging Technology and Advanced Engineering

Website: www.ijetae.com (E-ISSN 2250-2459, Scopus Indexed, ISO 9001:2008 Certified Journal, Volume 11, Issue 11, November 2021)

Thus, the basic elements of software, that is mathematical principles and rules expressed in algorithms, as such are not protected. However, the algorithms are interconnected with the program and are not directly protected with it.

A certain original form in which the algorithm is embodied by the author of the program is protected. The algorithm can be used from one program and implemented in another. With a huge number of programming languages (about 9,000), you can create many computer programs using the same algorithm, but the programs will differ in form of expression and in terms of copyright are independent and unique works. Free use of algorithms is allowed, provided that the independently created program contains the same algorithm, but is not essentially identical to the program that uses the same algorithm, but created by another author.

It is the possibility of unimpeded borrowing of algorithms that forces program authors to look for alternative remedies.

Suppose the author created a work (software) in the programming language $\mathrm{C}, \mathrm{C}$ \#, Java, JavaScript, PHP, C ++ , Objective-C, Perl, Python and formed a valid module for a particular operating system, say, Linux, Android or Windows. To legally use this author's software development, it is enough to decompile it, that is to convert the program from object code to a certain source text (code) in order to obtain the information necessary to achieve the interaction of the original software with another independently developed software. After that, the program is decomposed into modules, based on a clear algorithm of the program and compiled into another language (language platform), such as Visual Basic. According to the law, this will be another (new) work, although it uses the algorithm created by the original author.

All these inconsistencies, and the fact that copyright protects programs only completely, have ceased to satisfy the interests of their creators. Considering themselves software engineers, and not some writers, programmers turned their attention to patent law in the hope of improving "on the other bank" their financial situation [4-9].

Based on the above, the software in Ukraine is a specific object of legal regulation, which is conditionally equated to literary works.
In this case, this legislative equation is expressed by using the phrase "software is protected as literary works" in Art. 18 of the Law of Ukraine "On Copyright and Related Rights" and Part 4 of Art. 433 of the Civil Code of Ukraine, but, despite the obvious simplicity, can be misleading. The word "how" indicates the specifics of software's as a special result of intellectual activity, and the fact that programs are not in essence literary works, but simply have the same legal regime. Indeed, the basis of copyright protection is the protection of the form of the work, not its content.

Form is not the main of a software. Copyright protection does not always allow for the high-quality protection of an object such as a software. That is why the legislator in Ukraine provides for many special rules that can be applied to software's, including additional security measures.

Many countries eliminate the shortcomings of software copyright protection by simultaneously applying several institutions of intellectual property law - copyright and patent law. For example, Kaspersky Lab tries to protect its own software with copyright and patent law. The company already has more than 250 patents in Russia, the United States, China and Europe, including a patent for the program. The mixed method provides for the possibility of applying to software protection within other institutions of intellectual property law, such as protection in the mode of trade secrets and the termination of unfair competition, and so on. The system approach used to protect software rights includes the possibility of protecting them with patent rights.

In accordance with Part 3 of Art. 6 of the Law of Ukraine "On protection of rights to inventions and utility models" software are not included in the list of objects that cannot receive legal protection as inventions. It is only stated that software does not correspond to the concept of "invention (utility model)", but is an independent object. Accordingly, it is permissible to extend the legal regime of the invention to technologies related to software that is the law does not explicitly deny the possibility of patenting software, especially when the latter leads to a useful, concrete and material result. In fact, the mechanism of legal protection of a software in Ukraine has long gone beyond copyright. 


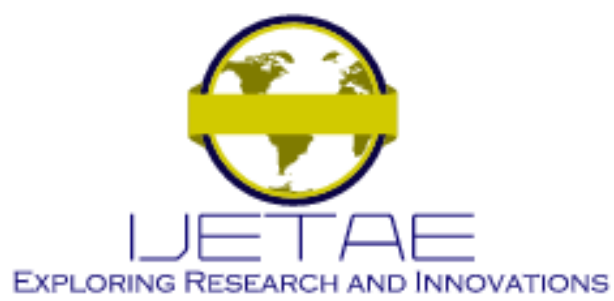

International Journal of Emerging Technology and Advanced Engineering

Website: www.ijetae.com (E-ISSN 2250-2459, Scopus Indexed, ISO 9001:2008 Certified Journal, Volume 11, Issue 11, November 2021)

The existing "technical essence" of the software makes this object of intellectual property atypical for the protection of copyright and significantly distinguishes it from the classic objects of copyright - works of literature, science and art. In essence, software drives a certain computational process that must result in a result that makes the software very close to the objects of patent law. This is evidenced by the case law of Ukraine, where the court found that the program is an invention (official), the essence of which was the method of computer identification of the individual by the image of his face $[1,3-5]$.

In addition, the definition of a software given in Art. 1 of the Law of Ukraine "On Copyright and Related Rights", practically describes not the form but the substantive essence (content) of the software using essential features (operating system, application program, expressed in source or object code). In fact, the legislator does not deny the possibility of protecting the software through its form and content, which is inherent in patent law for inventions. The normative definition of software is set out in order to cover all types and forms of its possible expression, but no attention is paid to the substantive part of this concept, which reveals the technical essence of the program. As a result, such a definition of a software is not characterized by simplicity, accuracy, unambiguity, which, in turn, creates problems in practice.

If we assume that the patent can protect the algorithm of the software as a way to solve a specific practical problem in a particular field of technology, the algorithm, namely its essence (functionality), and each stage are recorded and formalized in a clear verbal form, as well the necessary block diagrams, charts, graphs and other materials are provided. Assuming that the algorithm will be tested for patentability, it is likely that a patent for the invention will be obtained. Therefore, the most logical thing is to patent algorithms - the main component of software, as a sequence of precisely specified processes that are performed in a certain order. According to the same algorithm, the programmer can add strength to all sorts of programs. As you know, you cannot patent what is based either on the laws of nature or on the mental process. And algorithms are mathematical formulas that are the result of mental activity, and then it would be wrong to patent them.
In addition, patenting requires a rather complex, expensive and lengthy examination (from 2 to 5 years) of a software for absolute (global) novelty, during which the object itself may become obsolete and become unclaimed by potential users.

It should be noted that there is no software fund. For a software to receive reliable legal protection, it must differ significantly from existing technical solutions in a particular area of technology. Such a fund could simplify the identification of analogues, prototypes, with which it would be possible to compare the new solution, as well as to conduct an examination.

In the doctrine of patent law, the main criterion for the division of protected and unprotected inventions is the nontechnical nature of the latter. The purpose of any software is to control a technical device, to obtain a certain result with the help of a computer, which can be considered as a technical solution. Software can be recognized as solutions in the technical field. In the early 90's of XX century. The Federal Circuit, created specifically for patent cases, tried to understand this issue and found that if an invention consists only of mathematical algorithms, it is not patented. However, if the invention uses a computer to manipulate numbers that represent a specific, real value (for example, a software that translates electrocardiographic signals to prevent arrhythmia or a program that analyses seismic measurements), then such an invention is quite patentable. Accordingly, it is proposed to extend the application of patent law to decisions that are based on the use of standard computer technology for a new purpose, due to software.

In the legislation of EU countries such as Great Britain, Germany, in the Scandinavian countries, as well as in Art. 52 (2) and (3) of the European Patent Convention (EPC) state that software are non-patentable as such. This means that an invention related to a computer program can be classified as a patentable object if it leads to a technical result and is not software as such. The definition as such is understood as a feature of the claims in general and which provides a result in the art. Software is considered to be technical in nature if it is a source of technical influence when working on a computer. Moreover, this effect should be more than the usual physical interaction between the software and the computer. That is, the software must be more than a «program such» ("as such"). 


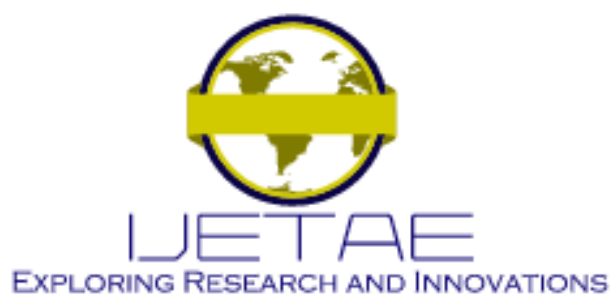

International Journal of Emerging Technology and Advanced Engineering

Website: www.ijetae.com (E-ISSN 2250-2459, Scopus Indexed, ISO 9001:2008 Certified Journal, Volume 11, Issue 11, November 2021)

In Europe, the phrase "as such" has made it possible to patent software. The fact is that Art. 52 The European Patent Convention excluded from the list of patents «software as such». It remains unclear what the phrase "as such" means, but many scholars have begun to argue that under this regulation, all software is patentable. Others have suggested that "as such" means that the software themselves are not patented, but if they are part of an invention, then they are patented.

The European Patent Office (EPO) pointed out that in the absence of a technical solution to a technological problem, an invention cannot be patented: a claim is considered patentable if it contains a technical feature, regardless of whether the feature derives from the prior art. This relatively low barrier is overcome when the hardware is turned on or when the software comes with a computer or memory device.

Thus, software is patentable if it leads and aims to solve a technological problem [3-7, 11]. However, obtaining a patent for a software is possible only in the presence of four features: "technical nature", "technical action", "technical contribution", "novelty, inventive step", "other EPC requirements" [10,12-16].

In the EU, the patenting of software is based on the provisions of the EPC, which has been clarified by a number of decisions of the European Patent Office. Thus, in case T0258 / 03 (Auction method / Hitachi) of 21 April 2004, the European Patent Office of Appeal stated that Art. 52 (1) and (2) EPC does not prohibit the patenting of software, but not every "technical solution" can be patented. The use of "technical means" to solve the problem implies the need to supplement the condition of "technical solution" and "innovation". The method using technical means is an invention according to the content of Art. 52 (1) EPC. The stages of the method, which consist of modifications of the business scheme and are aimed at bypassing the technical problem, rather than its solution by technical means, cannot contribute to the technical nature of the claimed object. Similar findings were made in case T 0928/03 (Video game / KONAMI) of 2 June 2006. The decision in case T 0154/04 (Estimating sales activity / DUNS LICENSING ASSOCIATES) of 15.11.2006 stated that software can be patented provided that they "solve" the existing technical problem (as, for example, speeding up the computer with improved memory access), and have an "innovative approach"[8, 22-29].
Thus, the European Patent Office issues patents for software's, recognizing them as "inventions implemented using a computer." The decision in case T 1173/97 of the European Patent Office states that a software is not excluded from patentability in accordance with Art. 52 (2) and (3) EPC, if when it is run on a computer and generates an additional technical effect that goes beyond the "normal" physical interaction between the program (software) and the computer (hardware). The software's must be technical in nature. The technical nature of software's can be manifested in the additional effects that result from the execution (hardware) of the instructions provided by the software. That is, when additional effects force the software to solve a technical problem.

Based on the Law of Ukraine "On protection of rights to inventions and utility models", as an invention (utility model) protects the result of human intellectual activity in any field of technology (Article 1), which meets specific and known conditions (novelty, inventive step) and industrial applicability) (Article 7). In the latest version of the Law of Ukraine "On protection of rights to inventions and utility models" software's that are an independent object does not correspond to the concept of "invention (utility model)" (Part 3 of Article 6). However, there is no explicit prohibition on patenting a software if it meets the conditions of patentability and leads to a technical result or the solution of a specific scientific and practical problem.

With the tacit consent of the legislator, patent protection can be granted at least to the methods of signal control embodied in the algorithm that is the basis of a computer program. To patent an algorithm and a software based on it, it is not necessary to circumvent the prohibition of patenting software's by using in the claims constructs such as: "computer (device) programmable to perform a function", "means of using a computer", etc. It can be other designs with all possible modifications which give the chance to receive legal protection for software's. Thus, in order to obtain patent protection for software, it is possible to state: a method that is carried out with the help of software; a device programmed to perform functions specified by software; information carrier, which differs only in the software recorded on it $[4,7,9,18]$.

However, according to paragraph 2.5 of the Rules for the preparation and submission of applications for inventions and applications for utility models "are not recognized as inventions (utility models) within the meaning of paragraph 1.2 of the Rules" software". 


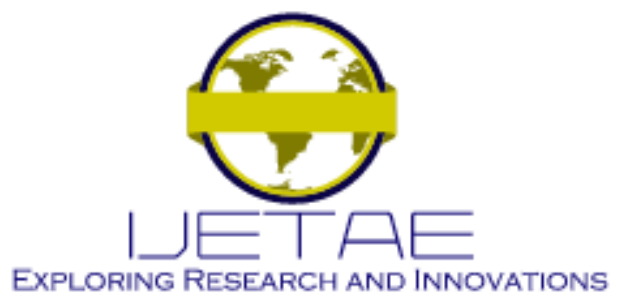

International Journal of Emerging Technology and Advanced Engineering

Website: www.ijetae.com (E-ISSN 2250-2459, Scopus Indexed, ISO 9001:2008 Certified Journal, Volume 11, Issue 11, November 2021)

Sergeev (2003). This raises the question: is it possible to obtain a patent for a software in Ukraine, based on Art. 1, 6 of the Law of Ukraine "On protection of rights to inventions and utility models". The Patent Office of Ukraine still issues patents for the protection of the "algorithm" (placed in the "technical environment", "technology"), without detailing some issues of establishing the "level of technology" and other criteria for patentability. For example, the patent for the system, method software provided to secure the transaction № 111650 dated 25.05.2016, bulletin № 10/2016, the patent owner - EINNOVATIONS HOLDINGS PTE. LTD., Singapore.

In general, the position of the legislator of Ukraine on the possibility of patenting software's is not clearly defined, and as a result - uncertainty in scientific circles and judicial practice. Although the prevailing view is that with the help of patent law it is permissible to provide protection to a software. Because the patent for the invention allows protecting the content of the software, patent protection extends to the entity embodied in the algorithm, which is the main idea of the program. In addition, the patent gives the exclusive right to the idea itself (if it is reflected in the essential features of the claims) and prevents its unauthorized use.

Ukrainian judicial practice in this area is just beginning to take shape. Thus, in case 752/9813/13-ts, the Court of Appeal of Kyiv stated in its decision that the software is an official invention, the essence of which is a way of computer identification of a person by depicting his face. In fact, the court found the software to be an invention and a technical one. Accordingly, case law and legislation do not explicitly state or deny the fact that software's may be protected by patent law, but under certain conditions.

Note that the patenting algorithms as software is essentially patenting an idea, as any software code is an implementation of some algorithms. Quite a lot of basic algorithms have been created for a long time and are based on classical mathematical models. Patenting of which is impossible in principle. The ability to patent an algorithm (idea) as software will slow down the development of innovative development of any state and prevent the formation of a free information society. Eventually, the software industry will become one of the most monopolized, where patents will be owned by large corporations that use them in competition with each other.

\section{CONCLUSIONS}

The issue of legal protection of software in Ukraine, as well as in EU countries, remains relevant today. However, for a number of historical reasons, software's and algorithms as such (per se) are non-patentable. Based on the scope of patent protection of inventions related to software's, it should be noted that such protection is in principle much broader than protection under copyright law. The experience of some foreign countries in this area shows a combination of copyright and patent law models for the protection of this object of intellectual property rights.

Therefore, it is expedient to consider the need to borrow in Ukraine the experience of foreign countries in using a comprehensive protection mechanism with certain elements of patent law. Or to develop a fundamentally new legal framework that would take into account the unique nature of software. The law on the protection of software rights should be abstracted from both literary works and technological results and provide for the protection of software, both in whole and in parts. This will not only prevent numerous violations by third parties regarding the illegal use of software, but also ensure the legal rights and interests of their developers (programmers).

\section{REFERENCES}

[1] Pro avtorske pravo i sumizhni prava: Zakon Ukrainy vid 23.12.1993 r. № 3792-XII. (1993). Vidomosti Verkhovnoi Rady Ukrainy, 13, art. 64.

[2] Pro okhoronu prav na vynakhody i korysni modeli: Zakon Ukrainy vid 15.12.1993 r. № 3769-XII. (1994). Vidomosti Verkhovnoi Rady Ukrainy, 7, art. 33.

[3] Vojnikanis, E.A. (2013). Pravo intellektual'noj sobstvennosti v cifrovuyu epohu: paradigma balansa i gibkosti. Moscow: ID «Yurisprudenciya».

[4] Tsyvilnyi kodeks Ukrainy: Zakon Ukrainy vid 16.01.2003 r. № 435 IV. (2003). Ofitsiinyi visnyk Ukrainy - Official Gazette of Ukraine, 11,7 .

[5] Act on Copyright and Related Rights (Copyright Act, as amended up to Act of September 1, 2017). URL: http://www.wipo.int/wipolex/ru/text.jsp?file_id=474263.

[6] Copyright, Designs and Patents Act 1988 (Chapter 48, incorporating amendments up to the Digital Economy Act 2017). URL: http://www.wipo.int/wipolex/ru/text.jsp?file_id=474030.

[7] Hospodarskyi kodeks Ukrainy: Zakon Ukrainy vid 16.01.2003 r. № 436-IV. (2003). Ofitsiinyi visnyk Ukrainy - Official Gazette of Ukraine, 11, art. 462.

[8] Directive 2009/24/EC of the European Parliament and of the Council of 23 April 2009 on the legal protection of computer programs (Codified version). URL: http://www.wipo.int/wipolex/ru/text.jsp?file_id=208107. 


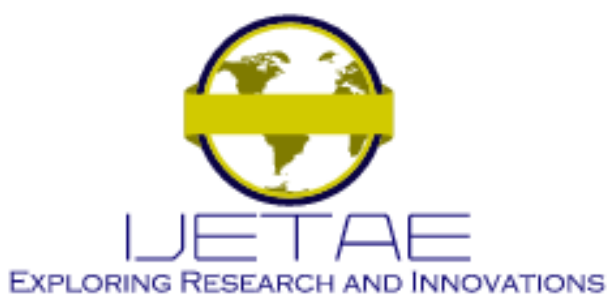

International Journal of Emerging Technology and Advanced Engineering

Website: www.ijetae.com (E-ISSN 2250-2459, Scopus Indexed, ISO 9001:2008 Certified Journal, Volume 11, Issue 11, November 2021)

[9] Agreement on Trade-Related Aspects of Intellectual Property Rights (TRIPS Agreement). http://www.wipo.int/wipolex/ru/other_treaties/details.jsp?group_id= 22\&treaty_id=231.

[10] WIPO Copyright Treaty (WCT) (Authentic text) (adopted in Geneva on December 20, 1996). URL: http://www.wipo.int/wipolex/ru/treaties/text.jsp?file_id=295157.

[11] Davies, S. (1998). Computer Program Claims. European Intellectual Property Review, 11, 429-433.

[12] Newman, J. (1998). The Patentability of Computer-related Invention in Europe. European Intellectual Property Review, 12, 701-708.

[13] Kaya, T. (2007). A comparative analysis of the patentability of computer software. Ankara Law Review, vol. 4, 1, 43-81.

[14] Vashchynets, I. (2004). Problemy udoskonalennia prav avtora na rozpovsiudzhennia u chynnomu zakonodavstvi Ukrainy. Intelektualna vlasnist, 1, 11-17.

[15] Zhuvanov, D. (2003). Yaku formu pravovoi okhorony obraty dlia komp'iuternoi prohramy. Intelektualna vlasnist, 9, 37-41.

[16] Svoja nosha ne tjanet: portfolio «Laboratorii Kasperskogo» popolnilos' dvumja desjatkami patentov. URL: http://www.kaspersky.ru/about/news/product/2014/svoya-noshanetyanet.

[17] Rishennia Apeliatsiinoho sudu m. Kyieva vid 16.09.2015 r. Sprava № 752/9813/13. URL: http://reyestr.court.gov.ua/Review/50793926.

[18] Borovskaja, E.A., Ermakovich, S.L., Kudashov, V.I., Losev, S.S., Uspenskij, A.A. (2010). Pravovaja ohrana komp'juternyh programm i baz dannyh.
[19] Schramm, C. (1957). Die shopferische Leistung. C. Heymanns Verlag. 266 p. URL: http://www.heymanns-download.de/schrammder-patentverletzungsprozess/.

[20] Sergeev, A.P. (2003). Pravo intellektual'noj sobstvennosti v Rossijskoj Federacii. Moscow: OOO «TK Velbi».

[21] European Patent Convention $1973 . \quad$ URL: https://wipolex.wipo.int/ru/text/312166.

[22] $\mathrm{T}$ 0258/03 (Auction method/HITACHI) of 21.4.2004. URL: https://www.epo.org/lawpractice/case-lawappeals/recent/t030258ep1.html.

[23] $\mathrm{T}$ 0928/03 (Video game/KONAMI) of 2.6.2006. URL: https://www.epo.org/lawpractice/case-lawappeals/recent/t030928eu1.html.

[24] $\mathrm{T}$ 0154/04 (Estimating sales activity/DUNS LICENSING ASSOCIATES) of 15.11.2006. URL: https://www.epo.org/lawpractice/case-law-appeals/recent/t040154ep1.html.

[25] T 1173/97 (Computer program product/IBM) of 01.07.1998. URL: https://www.epo.org/law-practice/case-lawappeals/recent/t971173ex1.html.

[26] European Patent Office. URL: https://www.epo.org/index.html.

[27] $\mathrm{T}$ 2539/12 (Searching a hierarchically structured database/SOFTWARE AG) of 18.01.2018. URL: https://www.epo.org/law-practice/case-lawappeals/recent/t122539eu1.html.

[28] Ofitsiinyi sait Ukrainskoho instytutu intelektualnoi vlasnosti (UKRPATENT).

URL:http://base.uipv.org/searchINV/search.php?action=viewdetails \&IdClaim $=223529$. 